TEME, г. XLIV, бр. 1, јануар - март 2020, стр. 267-283

\begin{tabular}{lr}
\hline Оригинални научни рад & https://doi.org/10.22190/TEME180423019V \\
Примљено: 23. 4. 2018. & UDK 640.4(497.113)
\end{tabular}

Ревидирана верзија: 29. 9. 2019.

Одобрено за штампу: 20. 2. 2020.

\title{
HOTEL-PRODUCT PERCEIVED QUALITY: A CASE STUDY OF CITY HOTELS IN VOJVODINA (SERBIA) - A FACTOR ANALYSIS
}

\author{
Svetlana Vukosav", Ksenija Wallrabenstein, Milan Bradić, Vuk Garača \\ University of Novi Sad, Faculty of Sciences, \\ Department of Geography, Tourism and Hotel Management, Novi Sad, Serbia \\ svetlana.vukosav@dgt.uns.ac.rs
}

\begin{abstract}
Over the past two decades, many researchers, as well as hotel management, conducted surveys on visitor satisfaction with service quality of hospitality products. However, there is a lack of investigation of the perceived quality of hotels products in Vojvodina whose economy is still in the stage of adjustment to the new economic conditions due to the transition and ownership transformation. Thus, the aim of this study is to identify all the specific factors of hotel product and to point out the necessity of strengthening them in order to reach the level of satisfaction of customers of services provided. Data were collected from a sample of guests staying at various city hotels in Vojvodina (Serbia), rated with 1 up to 5 stars. Two types of analyses were performed to reach this objective: the exploratory factor analysis (EFA) and after that, the one-way analysis of variance (One-way ANOVA) with the view of determining a substantive effect of factors in different hotel categories. The paper identifies five major attributes as the most influential factors of the hotel product quality, i.e. front office services, employees, hotel facilities, restaurant service and the location of facilities. The discussion of findings leads to some suggestions on how to reach the hotel-product improvement and the specialization of hotels.
\end{abstract}

Key words: city hotels, hotel product, perceived quality, factor analysis, Vojvodina (Serbia).

\section{ПЕРЦИПИРАНИ КВАЛИТЕТ ХОТЕЛСКОГ ПРОИЗВОДА: СТУДИЈА СЛУЧАЈА ГРАДСКИХ ХОТЕЛА У ВОЈВОДИНИ (СРБИЈА) - ФАКТОРСКА АНАЛИЗА}

\footnotetext{
Апстракт

Многи истраживачи, као и хотелски менаџмент, бавили су се истраживањем задовољства гостију и квалитетом услуга хотелског производа. Међутим, постоји недостатак истраживања перципираног квалитета хотелског производа у Војводини и Србији, чија привреда се и даље прилагођава новим економским
} 
условима пословања, што је резултат транзиције и процеса власничке трансформације. Дакле, циљ овог истраживања је да се идентификују сви специфични фактори хотелског производа и да се укаже на неопходност њиховог јачања да би гости били задовољни пруженим услугама. Подаци су прикупљени од гостију који бораве у различитим градским хотелима у Војводини (Србија), категорисаних у распону од 1 звездице до 5 звездица. Две врсте анализа су извршене да се постигне овај циљ: истраживачка анализа фактора (EFA) и анализа варијансе (једносмерна ANOVA), чијом применом би се утврдио суштински утицај фактора у различитим хотелским категоријама. Рад идентификује пет главних елемената као најутицајнијих фактора на квалитет хотелског производа: рецепција, запослени, хотелски садржаји, услуге ресторана и локација објеката. Дискусија резултата истраживања указује на предлоге како унапредити хотелски производ и на неопходност специјализације хотела.

Кључне речи: градски хотели, хотелски производ, перципирани квалитет, факторска анализа, Војводина.

\section{INTRODUCTION}

The mobility of tourism demand arises from the tourists' need to move to places where the service of their interest is offered. Thus, the main part of the tourist consumption usually occurs away from their place of residence and includes the spatial dispersion of service providers (Puciato et al, 2013). Nowadays, when ever changing patterns of customer needs and desires are visible in this competitive world, market research, as an inevitable tool for doing business, which acts as an aid in discovering new markets, helps understand the changing profiles of customers and also provides important information needed for new product development (Hodgson, 1990; Kozak \& Baloglu, 2011). The hotel management's main responsibility lies in providing a high quality service and hotel-product to the customers ( $\mathrm{Su}, 2004)$. Choi and $\mathrm{Chu}$ (2001) propose that in case hotels want to be successful in their business, they have to provide superior customer value in a continuous and efficient manner. Additional services of various types also may improve the competitiveness of hotels. All these issues are discussed by the tourists. If hotels want to develop positive customer experience, it is crucial to integrate various organization types such as marketing, operations, human resources, strategy, technology, social media and design (Kandampully et al., 2018). According to empirical evidence in related literature, we can emphasize that service quality and perceived quality of hotel-product have been well investigated. Over the past two decades, many researchers, as well as hotel management, have conducted surveys on visitor satisfaction in order to measure customer perception of quality attributes of the hotel and hospitality products. However, there is a lack of researches paying attention to the perceived quality of hotel industry in Vojvodina (Serbia) whose economy is still in the stage of adjustment to the new economic conditions due to the transition and ownership transformation. Therefore, modern hotel enterprises in Vojvodina do their business and 
develop within a new market dynamics setting, and face challenges that require engagement of optimal managing that would pay attention to critical factors such as satisfaction of all participants in business (Vukosav \& Curcic, 2009).

Consequently, the present study is developed using factor analyses, in order to find how hotel guests in city hotels examined the perceived performance of hotel facilities and services, as well as to improve their quality and the formation of product development strategy. The paper begins with an overview of literature on the importance of service quality, including evidence from the hotel industry. This is followed by the description of the research methods, the presentation and discussion on study findings, all in order to obtain relevant inferences, both for the theory and practice.

\section{LITERATURE REVIEW}

To form a hotel product practically means to achieve the consistency of the quality of its individual components and to provide harmonization in providing services by spatial and functional integration (Kosar \& Raseta, 2005). A hotel-product is nothing more than one chain of services coming out from the wishes and requests of the consumers, i.e. the hotel guests. Theoretically, it is determined by "location-space and view, courts, objects, equipment, services, price and image," "experience of the guests as an effect, not the structure of a hotel product" and it may be concluded accordingly that "location-space and services" stand at the base of a hotel product, whereas the core external elements are "service prices and hotel image" (KrsmanovićVeličković, 2017). In contemporary hotel literature there is the notion of "total hotel product" which comprises three elements: purpose or the core of the product, formal, i.e. physical product and extended product (Kosar, 2015). The development of international hospitality industry is moving towards specialisation and standardisation. In that sense, there is the tendency of equal quality at core level, i.e. physical product of a certain rank. The space for building an authentic expression is observed in the extended product, i.e. the extended value for the customers. The definition of the term 'value' as the real combination of quality, needs, expectations and price highlights the third level of a product, i.e. its extended dimension. In the extended dimension of a hotel-product, there is the essence of the added value for the guest.

Many authors have given a definition of service quality as an integral part of the hotel product. Similarly, Lewis \& Booms (1983) identified service quality as the measuring tool indicating how well the provided service matches the customers' expectations. Parasuraman, Zeithaml, \& Berry (1985) designed a conceptual model of service quality in some industries and proposed five gaps within the model, with the fifth one being defined as "the quality that a consumer perceives in a service as a function of the magnitude 
and direction of the gap between expected service and perceived service" (Parasuraman, Zeithaml \& Berry, 1985).

In their model, the expected service describes the consumers' expectations of the service which a company should provide, and the perceived service reveals the consumers' feelings about the actually provided service. Service quality is the key issue for keeping the guests and also an indicator of the future economic activities (Blesic et al., 2009). Hotel selection and attributes that are important to the travellers have been thoroughly researched by the application of a variety of methods (Chu \& Choi, 2000; Dolnicar, 2002). The perceived service quality emerges from the individual service encounter between the customer and the service provider. On that occasion, the customer evaluates the service quality and experiences either satisfaction or dissatisfaction (Bitner, Booms \& Stanfield, 1990). Butanaru and Miller (2012) define the service as a dynamic event during which the customers and staff may influence each other in many ways. Satisfaction of hotel service users and the competitiveness of the hotel offer will be guaranteed in case the management has excellent knowledge of customer preferences and their evaluation of the hotel services, as well as the willingness to allocate funds for certain services (Roman \& Martin 2016).

The awareness of the preferences of customers and the ability to be authentic with regard to the competition are critical success factors in the dynamic hotel market (Đorđević et al., 2016). The issues in providing high quality services that the hotel sector faces are high quality products creation and service delivery (Keating \& Harrington, 2002). Hotel services delivery entails frequent encounters and interaction between the customers, staff and facilities (Lovelock \& Wright, 1999) in which variability may be inherent and desirable. The management may be highly challenged in their attempt to balance the need for routine and standardization, on the one hand, with the need to treat customers as individuals, on the other. The aspects of service experience regarding basic hotel product have been ranked as the most important in the majority of the research, with the issue of cleanliness as the most important (Callan \& Bowman, 2000; Knutson, 1988; Lockyer, 2002; Weaver \& McCleary, 1991; Weaver \& Oh, 1993). According to Weaver and McCleary (1991), 90\% of business travellers ranked cleanliness as the most important aspect. Next to cleanliness there are other aspects of the core hotel-product, such as comfortable beds and rooms, and goodquality towels (Knutson, 1988; Weaver \& McCleary, 1991; Weaver \& Oh, 1993) that were also ranked as highly important. Further aspects of the hotel that were listed as being important for the process of selection included quality staff and service (Knutson, 1988; Lockyer, 2002; Weaver \& McCleary, 1991; Weaver \& Oh, 1993), safety and security (Knutson, 1988; Lockyer, 2002; Weaver \&d McCleary, 1991), as well as some extra values such as free newspapers and cable TV (Weaver \& McCleary, 1991; Weaver \& Oh, 1993). 
Currently, sustainable customer satisfaction remains one of the biggest challenges for managers in the hotel industry. Lu et al (2015) revealed that the guests conceptualize satisfaction in terms of value they received for the price of their accommodation. Relationships between the customers and the hotel that tend to be long-term and advantageous are becoming progressively important due to highly positive correlation between the guests' overall satisfaction levels and the probability of their return to the same hotel (Choi \& Chu, 2001). The hotel that is committed to a service culture for its customers will grow with the tourists, and will not dwell on past achievements. If the hotel does not "change" with its customers, the customers will change their selection of a hotel (Maniu \& Marin-Pantelescu, 2012).

Therefore, it is up to hotel managers to incorporate the perceived quality of service in their hotel product strategy and try to increase user retention that will help them to create, maintain, and sustain customer loyalty in order to eventually sustain competitive advantage (Ullah et al, 2016).

Hotels increase their investments intended for improving service quality and the perceived value of hotel products for their guests in order to achieve a better customer satisfaction and loyalty, as well as better the relationships with their customers (Jones et al., 2007). The perceived higher quality of hotel services leads to higher customer loyalty. If the loyalty of customers grows, it allows hotels to make savings by decreasing marketing costs, and positive communication by 'word of mouth' takes place instead. Moreover, the expenses of customers' change are lowered and the use of related products is increased (Jasinskas et al, 2016). The customers' experience of quality also has a significant effect on the increase in the number of returning customers. The quality of services that are provided by the hotel companies will be an important and useful factor in the recognition of hotels (Hosseini, 2015). The way in which customers perceive the quality of services they received is also important for managers since managers use it to develop or improve their own service quality standards with regard to the customers' evaluations and then direct employees to meet these standards (Dedeoğlu \& Demirer, 2015).

\section{METODOLOGY}

Our investigation on the quality of hotel products of Vojvodina was performed from May until September of 2017. The initial research took place in 20 city hotels of different categories. In Serbia, there is the 5-star hotel rating (hotels from 1 up to 5 stars), but we have divided all the hotels in our research in 3 groups in the following way: select service hotels (with 1 and 2 stars), mid-price hotels ( 3 stars), and upscale/luxury hotels (4 and 5 stars). We made this division because among the tourists themselves (and the professional public) all hotels with 1 and 2 stars are perceived as a unique 
group of select service hotels, then those with three stars as mid-price, and 4 and 5 star hotels as a separate group of upscale and luxury hotels.

The total of 420 guests participated in the research. Our questionnaire contains 2 groups of questions and respondents provided their attitude on the quality of the hotel-product. The first group of questions is related to the socio-demographic characteristics of the respondents, and the second part of questions related to 19 different elements of the hotel-product - elements based partly on the existing literature, and also on factors considered due to the specificities of the hotel-product of the city hotels in Vojvodina. On a Likert type five-degree scale, the respondents gave their opinion on each of the hotel-product element. For processing and analyzing the obtained results, the SPSS program and descriptive statistics were used. By factor analysis, specific factors of the city hotel-product of Vojvodina were isolated. In the sample of 420 respondents, $62.8 \%$ are male respondents, and $37.2 \%$ female respondents. In total, $64.3 \%$ of the respondents are domestic tourists (270), while foreign tourists amount to $35.7 \%$ of the sample ( 150 of them). Among the foreign tourists, there are tourists from 12 different countries, and their main motive of visiting is business (77\%). For domestic tourists, the dominant motive of visiting is also business (48\%), followed by recreation and leisure (29.2\%). However, regardless of the dominance of the business motive, both the foreign and domestic tourists stay in hotels of all three groups equally (Table 1), in spite of the prejudice that business tourists, as well as the foreign ones, mostly stay in premium hotels.

Table 1. Number and percent of tourists according to categories of the hotel

\begin{tabular}{|c|c|c|c|c|}
\hline & \multicolumn{3}{|c|}{ Hotel category } & \multirow[t]{2}{*}{ Total } \\
\hline & $\begin{array}{l}\text { select service } \\
(1 * 2 *)\end{array}$ & $\begin{array}{c}\text { mid price } \\
\left(3^{*}\right)\end{array}$ & $\begin{array}{l}\text { upscale/luxury } \\
\left(4 * 5^{*}\right)\end{array}$ & \\
\hline \multirow[t]{4}{*}{ Tourists domestic } & 87 & 84 & 99 & 270 \\
\hline & $32.2 \%$ & $31.1 \%$ & $36.7 \%$ & $100.0 \%$ \\
\hline & 57 & 39 & 54 & 150 \\
\hline & $38.0 \%$ & $26.0 \%$ & $36.0 \%$ & $100.0 \%$ \\
\hline \multirow[t]{2}{*}{ Total } & 144 & 123 & 153 & 420 \\
\hline & $34.3 \%$ & $29.3 \%$ & $36.4 \%$ & $100.0 \%$ \\
\hline
\end{tabular}

Source: Authors' own calculations by using the SPSS software

With regard to the age structure, the sample is mostly made from respondents of the age between 26 and 35 (30\%), and respondents of the age between 36 and 45 (29.9\%), while younger than 26 and older than 46 make, respectively, approximately $15 \%$ of the sample; there are only $8.8 \%$ respondents older than 56. In the educational structure of the visitors, there are mostly highly-educated respondents $(62.1 \%)$, then those with highschool education (31.4\%), and $6.4 \%$ of the respondents didn't give any statement on their education. Considering their monthly income, only $6.6 \%$ 
of foreign tourists have a monthly income less than 700 EUR, and $10.8 \%$ of the domestic tourists have monthly income higher than 700 EUR.

\section{RESULTS AND DISCUSSION}

Factor analysis was conducted with 19 value elements of the hotelproduct of the city hotels because of higher order factor determination. Three (3) items in total were not suitable for analysis, so the final factor analysis was performed with 16 items. In this way, 5 factors with the characteristic root higher than 1 were separated. Factors were rotated by Viramx rotation, with Kaiser normalization. Five separated factors explain the $75.5 \%$ variances in total (Table 2).

Table 2. Extracted factors of the city hotel-product elements

\begin{tabular}{|c|c|c|c|c|c|c|}
\hline \multirow[t]{2}{*}{ Component } & \multicolumn{3}{|c|}{$\begin{array}{c}\text { Initial } \\
\text { Eigenvalues }\end{array}$} & \multicolumn{3}{|c|}{$\begin{array}{l}\text { Extraction Sums of Squared } \\
\text { Loadings }\end{array}$} \\
\hline & Total & $\begin{array}{c}\% \text { of } \\
\text { Variance }\end{array}$ & $\underset{\%}{\text { Cumulative }}$ & Total & $\begin{array}{c}\% \text { of } \\
\text { Variance }\end{array}$ & $\underset{\%}{\text { Cumulative }}$ \\
\hline 1 & 5.701 & 35.632 & 35.632 & 5.701 & 35.632 & 35.632 \\
\hline 2 & 2.390 & 14.939 & 50.571 & 2.390 & 14.939 & 50.571 \\
\hline 3 & 1.832 & 11.451 & 62.022 & 1.832 & 11.451 & 62.022 \\
\hline 4 & 1.121 & 7.007 & 69.029 & 1.121 & 7.007 & 69.029 \\
\hline 5 & 1.036 & 6.475 & 75.504 & 1.036 & 6.475 & 75.504 \\
\hline 6 & .774 & 4.840 & 80.344 & & & \\
\hline 7 & .693 & 4.329 & 84.673 & & & \\
\hline 8 & .555 & 3.469 & 88.142 & & & \\
\hline 9 & .418 & 2.614 & 90.756 & & & \\
\hline 10 & .371 & 2.316 & 93.072 & & & \\
\hline 11 & .279 & 1.741 & 94.813 & & & \\
\hline 12 & .253 & 1.583 & 96.397 & & & \\
\hline 13 & .187 & 1.169 & 97.566 & & & \\
\hline 14 & .164 & 1.022 & 98.588 & & & \\
\hline 15 & .118 & .739 & 99.327 & & & \\
\hline 16 & .108 & .673 & 100.000 & & & \\
\hline
\end{tabular}

The internal consistency of the measuring instrument (with 16 items) was confirmed by the obtained Crombach alpha $(\alpha=.859)$, and obtained KMO (Kaiser-Meyer-Olkin Measure of Sampling), which assures the adequacy of sampling, and it amounts 0.774 .

Five separated factors of the hotel-product presented in Table 3 show similarity with the factors of higher order, obtained in recent research of different destinations. Emir \& Kozak (2011) state the following factors: front office services, employees, housekeeping, and food and beverage services. LeBlanc \& Nguyen (1996), in particular, examined the five hotel factors that 
may signal a hotel's image to travellers. These five factors were: physical environment, corporate identity, service personnel, quality of services and accessibility. Wilkins et. al. (2007) state three big groups of factors: physical product, service experience and the quality of food and beverage. Worsfold et al. (2016) investigated the key points of customer satisfaction and correlated them with the physical attributes of a hotel finding that these are significantly more connected with the intention of guests to return than satisfaction with the received services. In this research, the first obtained factor, F1, provides information on the hotel staff, and it covers items of efficiency and hospitability of the staff. This is not strange if we take into consideration the vast body of research, as well as relevant literature, that human resources are underlined as one of the most important value of the hotel-product of city hotels. The second isolated factor, F2, is called Hotel Facilities, and it covers items such as Entertainment Hotel facilities, Other Hotel Facilities and Other Services Offered by Hotel (the content outside of property which may be offered by the hotel to its visitors, for example excursions, visits, different happenings, etc). This factor is known in literature as one of undisputed value of the hotel-product, and in some cases, one of the most important and the most attractive elements (Chu \& Choi, 2000; Wilensky \& Buttle, 1988). The third factor isolated in this analysis, the factor, F3, is called the Food and Beverage, and it covers the following items: Food and Beverage Quality, Service in Food and Beverage and Efficiency of Food and Beverage Staff. It is interesting that the visitors saw the restaurant as a separate factor of the hotel value, practically as a subset of products, services and human resources within the whole (hotel) set of these elements. Moreo et al. (2019) described that customers in restaurants not only want the good food properly served, but also want it to be served with a smile. Customers expect to feel that the staff is genuinely happy to deliver services them. The fourth factor (F4), called Reception, is made of items called Availability and Intelligibility of Informative Facilities and Notices on the Reception Desk, as well as Information, Expertise and Attitude of Reception Staff. Despite the fact that hotel services are intangible, the hotel frontline employees may also render "tangible services" while directly interacting with their customers (Gonzalez \& Garazo, 2006; Harris, 2012; Kusluvan et al., 2010). It is for this reason that frontline employees are the critical elements of service quality.

The same as the factor Food and Beverage, the factor Reception is practically a separated entity. Also, a very important component of this factor is its informative purpose, so the factor Reception is partly related to information and the availability of information to the visitors of the hotel. The last separated factor, F5, is Location, i.e. the value of the hotel location itself, recognized in earlier research and literature as an important and standard element of the value of the entire hotel-product. Lewis \& Chambers (1989) perceived location as the most important factor which influences the selection of a hotel. Also, Tsaur \& Tzeng (1995) gave 
evidence on hotel location factors, including the convenience of transportation and parking, which were highlighted as the most important factors in the assessment process of the service quality of a hotel.

Table 3. Factors of city hotel product of Vojvodina, isolated by the factor analysis

\begin{tabular}{|c|c|c|c|}
\hline Factors/items & $\begin{array}{l}\text { Factorial } \\
\text { saturation }\end{array}$ & $\begin{array}{c}\text { Percentage } \\
\text { of explained } \\
\text { variance }\end{array}$ & $\begin{array}{c}\text { Crombach's } \\
\alpha \\
\end{array}$ \\
\hline F1 - The hotel staff & & 35.632 & .882 \\
\hline F1a Staff efficiency & .890 & & \\
\hline F1b Staff hospitability & .865 & & \\
\hline F2 - Hotel facilities & & 14.939 & .898 \\
\hline F2a Entertainment facilities in the hotel & .866 & & \\
\hline F2b Other facilities in the hotel & .877 & & \\
\hline $\begin{array}{l}\text { F2c Other services offered and provided } \\
\text { by the hotel }\end{array}$ & .821 & & \\
\hline F3 - Food and Beverage & & 11.451 & .833 \\
\hline F3a Quality of the food and beverage & .779 & & \\
\hline F3b Service in the food and beverage & .910 & & \\
\hline F3c Efficiency of food and beverage staff & .882 & & \\
\hline F4 - Reception & & 7.007 & .820 \\
\hline $\begin{array}{l}\text { F4a Availability and intelligibility of } \\
\text { informational facilities and notices at } \\
\text { the reception desk }\end{array}$ & .843 & & \\
\hline $\begin{array}{l}\text { F4b Information, expertise and attitude of } \\
\text { the reception desk }\end{array}$ & .821 & & \\
\hline F5 - Location & .801 & 6.475 & \\
\hline
\end{tabular}

Source: Authors' own calculations by using the SPSS software

The results of descriptive statistics of estimation for all 5 isolated factors of the city hotel-product of Vojvodina are showed in the Table 4.

Table 4. Indicators of descriptive statistics for 5 isolated factors.

\begin{tabular}{lccccc}
\hline & $\mathrm{N}$ & Minimum & Maximum & Mean & Std. Deviation \\
\hline F1 staff & 420 & 2.50 & 5.00 & 4.70 & .50784 \\
F2 facilities & 390 & 1.00 & 5.00 & 2.96 & 1.05032 \\
F3 food and beverage & 393 & 1.67 & 5.00 & 4.54 & .64627 \\
F4 reception & 408 & 2.50 & 5.00 & 4.26 & .66928 \\
F5 location & 420 & 2.00 & 5.00 & 4.61 & .63001 \\
\hline Valid N (listwise) & 366 & & & & \\
\hline
\end{tabular}

Source: Authors' own calculations by using the SPSS software

As seen in Table 4, four of five isolated factors were estimated as very satisfying, with the average score below 4 . It was only factor F2, which is related to facilities offered by the city hotels in Vojvodina, that 
was marked with a lower score $(M=2,6)$. According to scores, it can be noticed that (no matter what category) those hotels have satisfactory elements of product quality. The best rated factor, i.e. the highest quality of the hotel product of Vojvodina, have human resources $(M=4.70)$, as well as a location of hotel $(\mathrm{M}=4.61)$. Based on these results, it is possible to conclude that the employees in hotels in Vojvodina are extremely professional in doing their job and that they manage to satisfy most of the expected guests' needs. Also, locations of hotels are satisfactory and they reflect positively to the total quality. Hotel restaurants are also rated as satisfactory and they also reflect positively to the hotel product quality. Reception, as a separated factor, was rated with an average rate of 4,26 which means that it covers all needs, especially for information, but such an average rate shows that there is a significant space for improvement for the reception services performance on the whole, primarily in the sense of better informing the visitors relating to a variety of questions. The lowest average score $(\mathrm{M}=2.96)$ being more on the side of dissatisfaction than on satisfaction of the visitors, pertains to the factor called Hotel Facilities. It is well known that this hotel-product quality element makes a big influence to the total value and satisfaction of the visitors; it is very important to pay more attention, in the future, on the improvement and expansion of the range of facilities offered by city hotels in Vojvodina. The prominent feature of tourism and hospitality industry is their strong relationship with the entire offer of the tourist destination in which the business objects are located and the hotel-product created. High mutual dependence is caused by market features mostly in the sense of promotion and sale, as well as the demand of the customers for an integrated tourism product where the hotel product is the core part. Tourists arriving to Vojvodina for business or tourism purposes are oriented towards a variety of content provided by certain enterprises in the tourism industry within the destination. Thus, the management of the hotels and the development of the hotel-product have to be integrated into the framework of the development of Vojvodina as a tourist destination. In that sense the cooperation between all stakeholders in Vojvodina is indispensable. The lack of a managerial system and the coordination of the operations for all participants in the tourist destination lead to insufficient competitiveness of the tourist product in Vojvodina. Therefore, it is necessary to introduce the tourism management system of development through destination management at the provincial level.

So far, it has been determined that the three of five elements of the city hotel-product quality in Vojvodina are rated by the visitors as very satisfactory (F1, F5, F3), one factor as satisfactory (F4), and one doesn't meet the needs of the tourists in the best manner, and doesn't provide enough quality (F2). 


\section{THE STATISTICS OF MAKING CONCLUSIONS - THE OBTAINED FACTORS OF THE HOTEL PRODUCT QUALITY IN RELATION TO HOTEL CATEGORIES}

Following the survey, we have worked on the possible correlation between any statistically significant differences in estimation of the city hotel-product value factor among hotels of different categories, i.e. price tiers. For this type of analysis the F-test/ANOVA is used. Using this method enabled us to determine categories of hotels in which certain factors of quality should be improved.

By the application of a one-way analysis of variance (One-way ANOVA), it has been found that in hotels of different categories, there are statistically important differences in the rates of all factors of the hotelproduct value (Addendum 1, Table 1).

The factor F1 - Staff, although for hotels of all categories has been rated as the most valuble, shows statistically significant differences in average scores of hotels of different categories $(\mathrm{F}=9.108 ; \mathrm{df}=2$; Sig. $=0.000)$. Applying the Post Hoc LSD test, it was determined that the staff of upscale/luxury hotels was rated significantly better $(M=4.92)$ than the staff of mid-price hotels $(\mathrm{M}=4.52)$ and select service properties $(\mathrm{M}=4.60)$.

The second factor (F2- Facilities), also shows significant deviation in average rate among hotels of different categories, which leads to the much higher estimation of the facilities' quality in upscale/luxury hotels $(\mathrm{M}=3.82)$ in comparison to those in the mid-price range $(\mathrm{M}=2.84)$ and select service hotels $(M=2.27)$, while, at the same time, facilities of select service hotels were statistically rated lower than those of mid-price hotels.

Using analysis of the food and beverage estimated value as a factor of the hotel-product value, there two subsets of data are obtained. The first one contains average rates of upscale/luxury restaurants $(M=4.79)$ and midprice hotels $(\mathrm{M}=4.60)$, which are statistically better estimated than restaurants in select service properties $(\mathrm{M}=4.27)$.

Reception (F4), as a factor, is much better and of greater quality in upscale/luxury hotels $(\mathrm{M}=4.50)$ in comparison to mid-price $(\mathrm{M}=4.10)$ and select service hotels $(\mathrm{M}=4.01)$, which don't have any significant differences between themselves.

It is very interesting that location (F5), as a factor of the hotel product quality, statistically is rated much better in mid-price hotels $(M=4.95)$, in comparison to upscale/luxury $(\mathrm{M}=4.61)$ and select service hotels $(\mathrm{M}=4.39)$, whose locations were estimated as equally attractive, and without statistically significant difference. The implications of these results is the following: midprice hotels, mainly built during the 1960's and 1970's, when Vojvodina was in economic growth, imply that most of the city hotels in Vojvodina have extremely favourable location in the most frequent locations (such as the urban centres).

This analysis tells us that upscale/luxury hotels, in all factors of the hotel product quality (except location) are rated the highest, while select 
service hotels' all factors of hotel-product quality are rated the lowest. Mid-price hotels have the best locations in relation to hotels of other price tiers, and restaurants in them are rated very highly.

In upscale/luxury hotels (4 and 5 stars), the best rated factors are human resources and the restaurant. Reception service, especially in the sense of information providing is also a well estimated factor; however, it is necessary to follow continuously the visitors' needs and to be ready for adequate adjustments. Considering the location of upscale/luxury hotels, every change is practically impossible, but it is possible to directly affect the environment of the facility itself, and to try to improve at least that segment, in relation to the ambient, hygiene, external appearance and other possible aspects of the space directly surrounding these properties. The weakest points of all city hotels in Vojvodina are the facilities in the very hotels, as well as the additional services offered by the hotels. There is significant space for improvement, and it is necessary to approach this problem very seriously, especially concerning upscale/luxury hotels where the visitors have high expectations from this factor of quality. Every hotel enterprise which tends to have successful business has to orient their business operations towards achieving and maintaining high service quality. The hotels operating within a hotel group have a clearly defined relationship between brand and quality, which is also an important factor in perceiving service quality of such objects by the customers. Moreover, high and precisely defined standards in providing hotel services decrease the gap between the expected and the perceived service quality. In order to achieve and maintain the quality of their hotel product independent hotels must also tend to apply standards in their business. Standards that are applied, from the building and equipping the object, to the control and management processes, ensure the quality base and minimize improvisations and irrational business activities, and even improve the value and quality of the product.

Mid-price hotels (3 stars) have the highest scores for location and that is their significant advantage. This factor should be especially emphasized in the promotional activities and used as the most important "attracting" factor for the visitors. Food and Beverage in mid-price hotels are a very important factor of the product value which gives us a good starting point for forming a typical Vojvodina hotel-product, taking into consideration that Vojvodina is building its image of the destination with excellent gastronomy, as well as a region of very beautiful natural and ambient values. A good location, in beautiful surroundings, with excellent restaurants may create a great base for a good image, but also for improvement of other factors of quality, primarily the facilities.

Select service hotels (1 and 2 stars) are not considered as the hotel products from which we can expect much. However, even in this tier, all factors of quality (except for facilities) have been rated by the visitors as satisfactory, but there is space for improvement of the reception service and food and beverage. Facilities are considered as a weak factor of select 
service hotels, especially because it is not expected from these hotels to offer many attractive facilities to the visitors. However, there are some possibilities for involving some additional facilities which do not require big space and investments, but creativity. In that sense, the market should be researched; in creating business policy of a hotel, it is very necessary to aim for the specialization of the facilities, which means focusing on the narrower segments of the demand, offering an adjusted and adequate product. If we compare hotels that have undergone the owner transformation process (mostly mid-price hotels) to other hotels in town centres in Vojvodina, we may detect certain differences in management types and business orientation between the two groups of hotels. The greatest problems of the public sector hotels and state-owned hotels are the poor allocation of resources, insufficient innovation aimed at improving the quality of the hotel-product, market behaviour and the management of total enterprise activities, as well as the total lack of the ability to adapt to the changes of the tourist market, especially with regard to the changes and requirements in terms of the tourist demand. Those hotels continue to focus on the hotel service and processes of rendering the service contrary to the contemporary trends that direct towards customers and their preferences.

\section{CONCLUSION}

In the present research, the factors, "hotel facilities", "employees", have been isolated as individual elements, which means that they deserve special attention and harmonization with other isolated elements (location, reception, restaurant) in order to create a complete picture of the hotelproduct capable of satisfying all the expectations of the guests. Our findings indicate that a small number of hotels offer guests services outside the properties in cooperation with certain cultural and other institutions, and it is considered to be the weak point in market positioning of the total accommodation offer. On the other hand, the factor of hotel staff is the best valued element of hotel-products. The results of the research indicate that high category hotels have been estimated as higher quality according to 4 quality factors of the hotel-product (staff, facilities, restaurant, reception), whereas low category hotels, in all quality factors of the hotel-product, have been estimated with a lower rating. Moreover, the medium category hotels occupy the best locations in town centres in contrast to the hotels of other categories. The restaurants in medium category hotels have also been estimated as high quality. The processes and the complexity in the tourist market require the management of hotel enterprises in Vojvodina to make a continued effort in finding new strategies, innovations and to create new elements of the city hotel-product, as well as make adjustments to the strategy so as to adapt to new tendencies which would enable them to respond to any new tourist-requests, and to keep and improve the position in 
the market, as well as to respond successfully to the competitive pressures and challenges.

After the ownership transformation process, all hotel enterprises in Vojvodina still have not found their place in the tourist market because the city hotels' offers may be seen as too "something for all". In contemporary business conditions, it is imperative to specialize hotels in accordance with the target group. The facts considered as very important in the process of the hotel-product adjustment to the tourist demands are investments, education and the specialization of the existing staff, especially the managing structures. The research that has been conducted for this paper has certain limiting factors, i.e. restrictions. First of all, the respondents' answers may be taken as based on their subjective estimation. Since the questionnaire was anonymous, the impact of subjectivity was diminished, however there is also the factor of the social desirability bias of the respondents. Furthermore, there is the impact of the cultural, social and economic differences regarding the origin of the respondents (Slovenia, Croatia, Serbia, Montenegro, Italia, Austria, Russia, etc.), and there are also restrictions regarding the interpretation of the results due to the variety of perceptions of certain services which emerged under the influence of these differences. On the one hand, the restrictions of the research refer to the lack of any previous research in Vojvodina (Serbia), thus the results of the conducted research could not be compared the any preexisting data. On the other hand, this is, at the same time, the advantage of the conducted research since it is the very first research dealing with the influence of the perceived quality of service in city hotels in Vojvodina (Serbia).

\section{REFERENCES}

Bitner, M. Booms, B.H. \& Stanfield, T.M. (1990). The service encounter: diagnosing favourable and unfavorable incidents, Journal of Marketing, 54(1), 71-84.

Blesic, I., Romelic, J. \& Bradic, M. (2009). Primena modifikovanog SERVQUAL modela u oceni kvaliteta hotelskih usluga na primeru Zapadnomoravske banjske zone [Application of a modified SERVQUAL model in assess the quality of hotel services on the example of the West Moravian Spa Zone], Journal ofthe Geographical Institute Jovan Cvijic, 59(1), 93-110.

Butanaru, G.I., \& Miller, A. (2012). Conceptual approaches on quality and theory of tourism services, Procedia Economics and Finance 3, 375 - 380.

Callan, R., Bowman, L. (2000). Selecting a hotel and determining salient quality attributes: a preliminary study of mature British travellers, International Journal of Tourism Research, 2(2), 97-118.

Choi, T., \& Chu R. (2001). Determinants of hotel guests' satisfaction and repeat patronage in Hongong hotel industry, International Journal of Hospitality Management, 20(3), pp. 277-297.

Chu, R., Choi, T. (2000). An importance-performance analysis of hotel selection factors in the Hong Kong hotel industry: a comparison of business and leisure travellers, Tourism Management, 21(4), 363-377.

Dedeoğlu; B. B., \& Demirer, H. (2015). Differences in service quality perceptions of stakeholders in the hotel industry, International Journal of Contemporary 
Hospitality Management, 27(1), 130-146. https://doi.org/10.1108/ IJCHM-082013-0350

Dolnicar, S. (2002). Business travellers' hotel expectations and disappointments: a different perspective to hotel attribute importance investigation, Asia Pacific Journal of Tourism Research, 7(1), 29-35.

Đorđević, A., Zečević, B., Stančić, B.H. (2016). Importance of various service types in hotels - empirical analysis, Economic themes, 54(3), 403-423. DOI 10.1515/ ethemes-2016-0020

Emir, O. \& Kozak, M. (2011). Perceived importance of attributes on hotel guests' repeat visit intentions, Journal Tourism, 59(2), 131-143.

Gonzalez, J. V., \& Garazo, T. G. (2006). Structural relationships between organizational service orientation, contact employee job satisfaction and citizenship. International Journal of Service Industry Management, 17(1), 23-50.

Harris, L. C. (2012). Ripping off tourists: An empirical evaluation of tourists' perceptions and service work (mis)behavior. Annals of Tourism Research, 39(2), 1070-1093.

Hodgson, P. (1990). New Tourism Product Development: Market Research's Role, Tourism Management, 11(1), 2-5.

Hosseini, S.R., Zainal, A., \& Sumarjan, N. (2015). The Effects of Service Performance of Hotel Customers on Quality of Experience and Brand Loyalty in Iran, Procedia Social and Behavioral Sciences, 201, 156-164.

Jasinskas, E., Streimikiene, D., Svagzdiene, B., \& Simanavicius, A. (2016). Impact of hotel service quality on the loyalty of customers, Economic Research-Ekonomska Istraživanja , 29 (1), 559-572. https://doi.org/10.1080/1331677X.2016.1177465

Jones, D., Mak B. \& Sim J. (2007). A New Look at the Antecedents and Consequences of Relationship Quality in the Hotel Service Environment, Services Marketing Quarterly, 28(3), 15-31.

Kandampully, J., Zhan, T. \& Jaakkola, E. (2018). "Customer experience management in hospitality. A literature synthesis, new understanding and research agenda", International Journal of Contemporary Hospitality Management, 30 (1), 2156. https://doi.org/10.1108/IJCHM-10-2015-0549

Keating, M., \& Harrington, D. (2002). The challenges of implementing quality in the Irish hotel industry: A review, Managing Service Quality, 12(5), 303-315.

Knutson, B. (1988). Frequent travelers: making them happy and bringing them back, Cornell Hotel and Restaurant Administration Quarterly, 29(1), 83-87.

Kosar, Lj., \& Rašeta, S. (2005). Izazovi kvaliteta [ Quality challenges], Viša hotelijerska škola, Beograd

Kosar, Lj. (2015). Osnove hotelijerstva [Basics of hotel industry], Visoka hotelijerska škola, Beograd

Kozak, M., \& Baloglu, S. (2011). Managing and Marketing Tourist Destinations: Strategies to Gain a Competitive Edge, Routledge, New York

Krsmanović-Veličković, S. (2017). Dizajniranje u hotelijerstvu kao faktor diferenciranja hotelskog proizvoda, doktorska disertacija u rukopisu [Designing in hotel industry as a factor of differentiation of hotel products, doctoral dissertation in manuscript], Univerzitet Singidunum, Departman za posledipolomske studije, Beograd

Kusluvan, S., Kusluvan, Z., Ilhan, I., \& Buyruk, L. (2010). The human dimension: A review of human resources management issues in the tourism and hospitality industry. Cornell Hospitality Quarterly, 51(2), 171-214.

LeBlanc, G., \& Nguyen, N. (1996). An examination of the factors that signal hotel image to travelers, Journal of Vacation Marketing, 3(1), 32-42.

Lewis, R., \& Booms, B. (1983). The marketing aspects of service quality: Emerging perspectives on services marketing, Chicago: American Marketing 
Lewis, R., \& Chambers, R. (1989). Marketing Leadership in Hospitality, Van Nostrand Reinhold, New York

Lockyer, T. (2002). Business guests' accommodation selection: the view from both sides, International Journal of Contemporary Hospitality Management, 14(6), 294-300.

Lovelock, C., \&Wright, L. (1999). Principles of service marketing and management, Englewood Cliff, NJ: Prentice-Hall

Lu, C., Berchoux, C., Marek, M.W., \& Chen, B. (2015). Service quality and customer satisfaction: qualitative research implications for luxury hotels", International Journal of Culture, Tourism and Hospitality Research, 9(2), 168-182. https://doi.org/10.1108/IJCTHR-10-2014-0087

Maniu, L.A., \& Marin-P antelescu, A. (2012). Managing the Hotels Service Products and E-Services. Case Study: Researching Tourists' Satisfaction Regarding the Hotels Services in Romania Journal of Knowledge Management, Economics and Information Technology, 8, 1-14.

Moreo, A., Woods, R., Sammons, G., \& Bergman, C. (2019). "Connection or competence: Emotional labor and service quality's impact on satisfaction and loyalty", International Journal of Contemporary Hospitality Management, 31( 1), 330-348, https://doi.org/10.1108/IJCHM-03-2017-0176

Parasuraman, A., \& Zeithaml, V. \& Berry, L. (1985). A conceptual model of service quality and its implications for future research, Journal of Marketing, 49(4), $41-50$.

Puciato, D., Łoś, A., \& Mrozowic, K. (2013). Franchising as a way of reducing moral hazard in the tourism market, Argumenta Oeconomica, 1 (30), 127-147.

Roman, C., \& Martín, J.C. (2016). Hotel attributes: Asymmetries in guest payments and gains-A stated preference approach, Tourism Management, 52, 488-497. https://doi.org/10.1016/j.tourman.2015.08.001

$\mathrm{Su}$, A. (2004). Customer satisfaction measurement practice in Taiwan hotels, International Journal of Hospitality Management, 23(4), 397-408.

Tsaur, S., \& Tzeng, G. (1995). Multiattribute decision making analysis for customer preference of tourist hotels, Journal of Travel \& Tourism Marketing, 4(4), 55-69.

Ullah, A., Raza, M., \& Chander, S. (2016). Effect of perceived quality of service on customer loyalty: a case of pearl continental hotel services, City University Research Journal, 6(1), 81-100.

Vukosav, S., \& Curcic, N. (2009). Promene u hotelijerstvu Vojvodine kao rezultat tranzicionih procesa [Changes in the hotel industry of Vojvodina as a result of the transition process], Journal of the Geographical Institute Jovan Cvijic, 59(1), 139-154.

Weaver, P., McCleary, K. (1991). Basics bring 'em back, Hotel and Motel Management, Dululth.

Weaver, P., \& Oh, H. (1993). Do American business travellers have different hotel service requirements? International Journal of Contemporary Hospitality Management, 5(3), 16-21.

Wilensky, L., \& Buttle, F. (1988). A multivariate analysis of hotel benefit bundles and choice trade-offs, International Journal of Hospitality Management, 7(1), 29-41.

Wilkins, H., Merrilees, B. \& Herington, C. (2007). Towards an understanding of total service quality in hotels, Intenational journal of Hospitality Management, 26(5), 840-853.

Worsfold, K., Fisher, R., McPhail, R., Francis, M., \& Thomas, A. (2016). Satisfaction, value and intention to return in hotels, International Journal of Contemporary Hospitality Management, 28(11),2570-2588. https://doi.org/ 10.1108/IJCHM-04-2015-0195. 


\title{
ПЕРЦИПИРАНИ КВАЛИТЕТ ХОТЕЛСКОГ ПРОИЗВОДА: СТУДИЈА СЛУЧАЈА ГРАДСКИХ ХОТЕЛА У ВОЈВОДИНИ (СРБИЈА) - ФАКТОРСКА АНАЛИЗА
}

\author{
Светлана Вукосав, Ксенија Валрабенштајн, Милан Брадић, Вук Гарача \\ Универзитет у Новом Саду, Природно-математички факултет, \\ Департман за географију, туризам и хотелијерство, Нови Сад, Србија
}

\begin{abstract}
Резиме
Многи истраживачи бавили су се истраживањем хотелског производа и његовог квалитета, но мали је број истраживања која су на ову тему спроведена у Србији и Војводини. У овом тренутку процеси и сложености на туристичком тржишту, након транзиције, власничке трансформације и економске кризе у нашој земљи захтевају од менаџмента хотелских предузећа непрекидан и континуирани напор ка изналажењу нових стратегија, иновирању и стварању новог туристичког производа, прилагођавању стратегије новим тенденцијама како би у потпуности одговорили новим захтевима туриста, одржали и унапредили позицију на тржишту и успешно одговорили конкурентским притисцима и изазовима. Истраживање на тему квалитета хотелског производа Војводине вршено је у периоду од маја до септембра 2017. године. Истраживање је спроведено у 20 градских хотела различитих категорија на територији читаве Војводине. У истраживању је учествовало 420 испитаника. Испитаници су се изјашњавали о свом виђењу квалитета градског хотелског производа на анкетном упитнику, који је садржао две групе питања. Прва група питања односила се на социо-демографска обележја испитаника, а други део упитника чинио је списак питања која су истраживала 19 различитих елемената хотелског производа, одабраних прегледом литературе, али и увидом у неке специфичности хотелског производа у самој Војводини. На петостепеној скали Ликертовог типа испитаници су се изјашњавали посебно о сваком од елемената хотелског производа. За обраду и анализу коришћен је SPSS програм и дескриптивна статистика. Факторска анализа спроведена је са 19 вредносних елемената хотелског производа Војводине ради утврђивања фактора вишег реда. Укупно три ајтема нису била погодна за анализу, те је коначна факторска анализа извршена са 16 ајтема. На овај начин издвојено је 5 фактора са карактеристичним кореном већим од један. То су: особље хотела, хотелски садржаји, ресторан, рецепција и локација. У постојећем истраживању фактори хотелски садржаји и запослени су се издвојили као засебан елемент, што значи да ови елементи хотелског производа заслужују посебну пажњу и усклађивање са осталим елементима да би укупна слика хотелског производа задовољила очекивања туриста. Аутори закључују да веома мали број хотела нуди садржаје гостима изван објекта, као и у оквиру објекта, што представља слабу тачку у позиционирању укупне смештајне понуде на туристичком тржишту. Након спроведеног процеса својинске трансформације, хотелска предузећа у градовима Војводине још увек „лутају” на туристичком тржишту тражећи своје госте, јер досадашња понуда градских хотела у Војводини била је у складу са изразом „за сваког по нешто”. У савременим условима пословања мора се ићи ка што ужим сегментима тражње, уз неопходну специјализацију објеката у складу са циљном групом. Оно што се сматра за значајно у прилагођавању хотелског производа туристичкој тражњи јесу инвестиције, као и едукација и усавршавање постојећег кадра, поготово менаџерских структура.
\end{abstract}

